\title{
Nodule bacteria in the remediation of soil contaminated by drilling waste
}

\author{
M.A. Zimnukhov ${ }^{1}$, A.E. Zimnukhova ${ }^{2}$, A.O. Rusakovich ${ }^{3}$, O.Sh. Beliavskaia ${ }^{4}$ \\ ${ }^{1}$ Gazpromneft Specialized Department, Institute of Civil Engineering, FSBEI HE Industrial \\ University of Tyumen, Russia \\ ${ }^{2}$ Department of Technosphere Protection, Institute of Service and Industry Management, FSBEI HE \\ Industrial University of Tyumen, Russia \\ ${ }^{3}$ Department of Construction Production, Institute of Civil Engineering, FSBEI HE Industrial \\ University of Tyumen, Russia \\ ${ }^{4}$ Department of Building Design and Urban Planning, Institute of Civil Engineering, FSBEI HE \\ Industrial University of Tyumen, Russia
}

\begin{abstract}
The paper studies the possible application of salt-tolerant strains of nodule bacteria such as 340b, 348a, 1360, 367a, 363a, 375a for clover and lupine in bioremediation of the soil contaminated by drilling waste in the Tyumen Region. Chemical composition of drilling sludge at the Nivagal'skoe oil field in KMAO (cluster № 924) was determined using XRF analysis, eight types of salinization wereidentified: $\mathrm{MgSO}_{4}, \mathrm{Na}_{2} \mathrm{SO}_{4}$, $\mathrm{NaCl}, \mathrm{NaHCO}_{3}, \mathrm{Na}_{2} \mathrm{CO}_{3}$, sulfate-soda, sulfhate-chloride, and gypsum. Laboratory studies on nodule bacteria survival were carried out. Inhibiting influence of most salinization types was found, however, all samples have shown positive survival. Moreover, increaseof essential nutrients in the soil was noted. These results indicate that the application of given strains in the remediation of soil contaminated by drilling waste- is possible.
\end{abstract}

\section{Introduction}

Petroleum industry produces a large impact on all kinds of ecosystems. Environmental pollution caused by oil exploration leads to severe environmental and economic damage [1].

Analysis of oil and gas deposits in Russia (Fig. 1) shows that they are primarily concentrated in Western Siberia.Since the amount of oil and gas industry waste is proportionalto extraction volume, the waste management issue is of great importance in this region. 


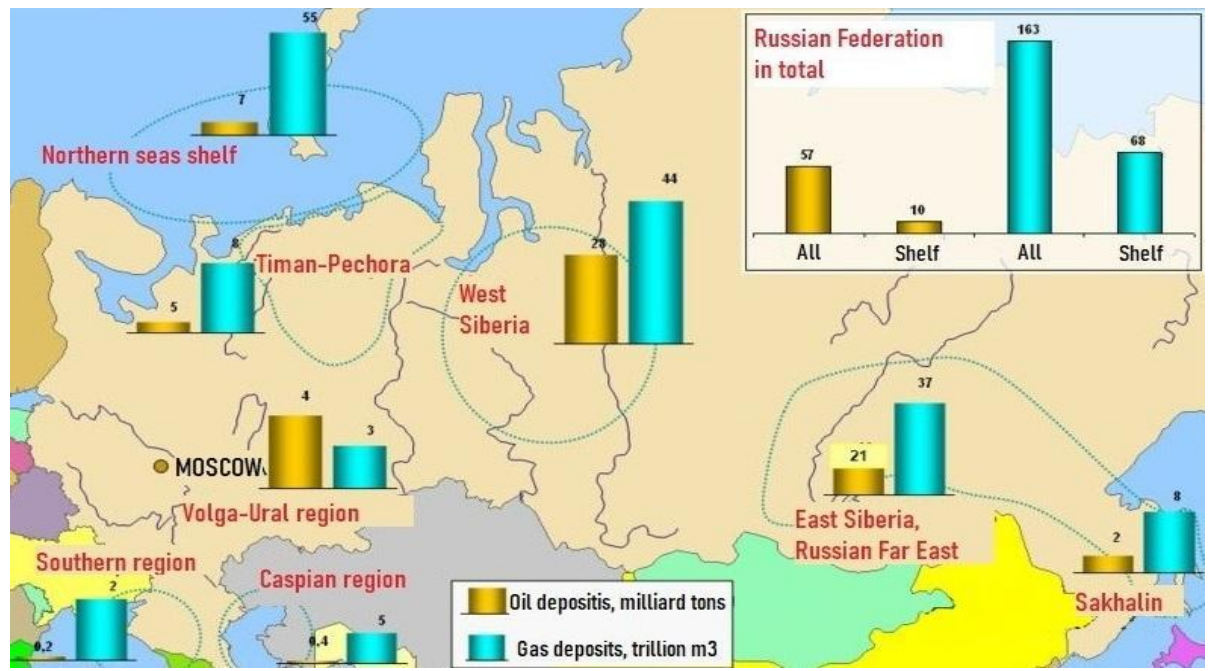

Fig. 1. Oil and gas deposits in the Russian Federation.

The Khanty-Mansi Autonomous Okrug - Yugra (KMAO) is the main oil and gasproducing region in Russia andthe world's largest oil exploration area. 236.5 million tons of oil was extractedin 2019 in KMAO which makes $42.5 \%$ of nationwide oil production. The volume of exploitation drilling amounted to 17.7 million $\mathrm{m}^{3}, 5017$ new production wells were put intooperation (Animal, forest, and environment control service of Khanty-Mansi Autonomous Okrug 2020).

87 licensed mining companies with longtermmining licenses operate in KMAO. The data of the Regional Waste Inventory show that 76 sludge pits were closed and 6 new sludge pits were constructed in 2019 (Fig. 2). 147 waste disposal sites (sludge pits) owned by 8 companies are not closed as of 1 January 2020 .

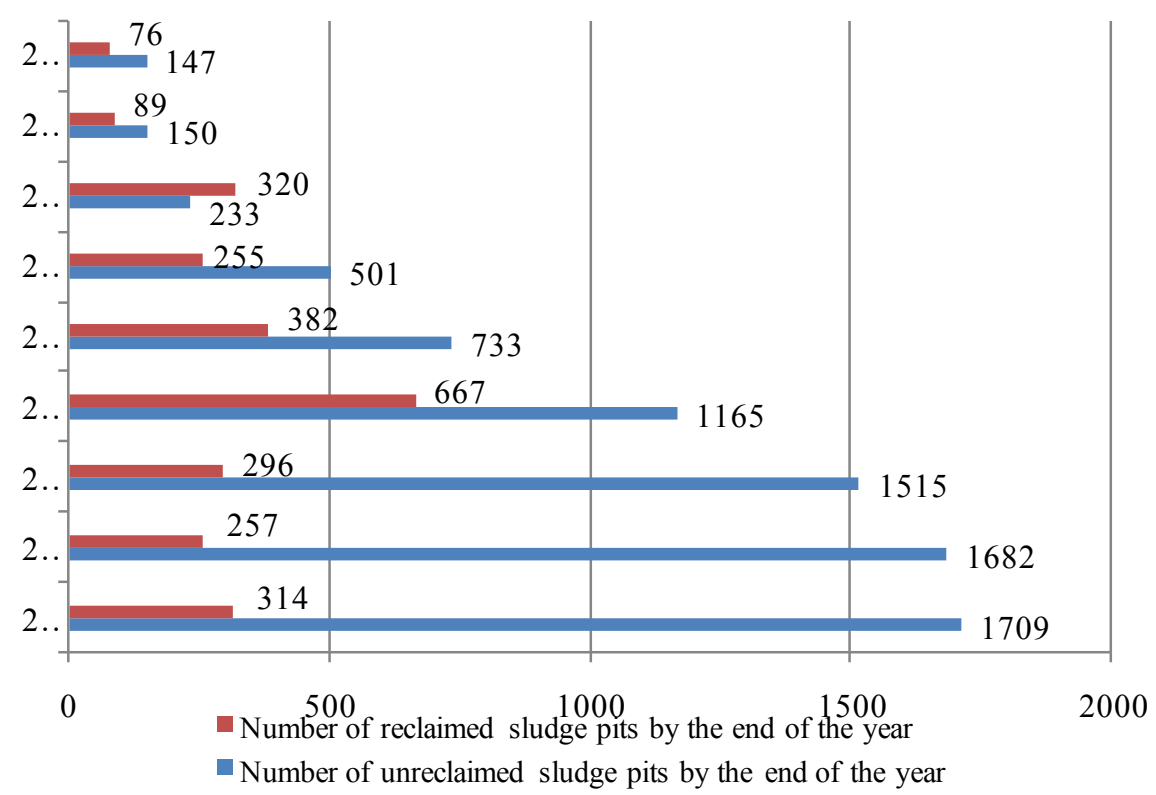

Fig. 2. Sludge pits construction and closure dynamics. 
The degree of filling of landfill sites in operation varies from $0.5 \%$ to $87.7 \%$.

All these data show a great need for an effective approach to sludge pit remediation.

The Khanty-Mansi Autonomous Okrug - Yugra is located in the middle of the West Siberian Plain. The average annual temperature varies from $0^{\circ} \mathrm{C}$ in the south to $-5^{\circ} \mathrm{C}$, the annual cycle of temperature is typical of the continental climate.

The harsh climate requires a specific approach to sludge pit reclamation.

Sludge pit construction and operation, as well as the remediation of the occupied land, comprises several stages:

1. Sludge pit design and construction;

2. Sludge pit operation during drilling work;

3. Sludge pit decommissioning;

4. Design documentation development;

5. Technical measures for reclamation;

6. Bioremediation;

7. Re-zoning the lands for forestry use [2].

At present time, sludge pits are to be backfilled and reclaimed once the drilling works are completed. Backfilling results in an accumulation of drilling waste, and reclamation with seed mixtures does not achieve its primary goal of ecosystem rehabilitation because the soil lacksthe necessary nutrients. This indicates that the addition of nutrients-producing microorganisms may be needed.

The nodule bacteria are an example of such microorganisms. Their application is characterized by the fact that they can live only on legumes roots. Being able to fix inorganic atmospheric nitrogen, the nodule bacteria makes the soil more fertile, which results in a better harvest. This leads to the formation of organonitrogen compounds which can be used instead of mineral fertilizers and stimulate plant growth and maturation. It is also remarkable that strains of nodule bacteria reduce the phytopathogenic reproduction and increase plant resistance to adverse conditions.

The study aims to investigate the effect of the concentration of drilling sludge salts on nodule bacteria activity. According to the aim of the study, the following tasks were set:

- To determine the chemical composition of drilling sludge;

- To find the drilling sludge salts with the most adverse impact on living organisms;

- To determine the parameters for activity of the salt tolerant strains of nodule bacteria in an experimental study;

- To obtain a perspective way of bioremediation of a drilling waste-contaminated soil.

\section{Review of literature}

A review of literature has shown that different means for reclamation of soilscontaminated by drilling waste are developing. There are two main means which are highlighted: bioremediation and phytoremediation [3]. The first means suggests the application of microorganisms that can destroy the remains of hydrocarbon raw material. It is necessary to makecrop tillage and fertilize the soil regularly. One of the disadvantages of this method is the necessity to maintain a positive temperature of soil (at least $15^{\circ} \mathrm{C}$ ), which makes it inefficient in North and Arctic, where most of the oil and gas deposits is concentrated [4]. Phytoremediation suggests the sowing of grass mixtures that can survive in relatively low hydrocarbons soils. The grass mixtures mostly consist of such plants as timothy grass, white clover, red fescue grass, dock, meadow grass, etc. [5]. This method is also ineffective in a harsh climatesince a low average annual temperature significantly reduces the vegetation period.

The bioremediation method seems to be of great interest within the given study. The term "bioremediation" means biological soil cleanup using different technologies and 
devices for the removal of existing contaminants [6]. There are two main bioremediation approaches:

1. Biostimulation, i.e.the introduction of different substrates, oxygen, biogenic elements for activation of degrading microflora capacity

2. Bioaugmentation, i.e. the introduction of specially created decomposer strains.

Biostimulation leads to the increasing amount of microorganisms that are able to clean up the soil. However,the microorganisms' efficiency is relatively low due to the lack of nitrogen compounds, phosphorus, potassium, and other biogenic components and adverse physical and chemical conditions [7].

Earthworms are also used for the clean-up of contaminated soils. This leads to increasing in soil porosity and raises its structural organization. This results in the improvement of aerating and water status of soils $[8,9]$.

Soil cultivation (loosening, disk plowing, tillage) speeds up the oil and petroleum product decomposition, which contributes to the self-regeneration of soil ecosystems. It is to be noted that periods of self-regeneration can vary from 2 years in the south to $15-20$ years in the north depending on the level of contamination and environmental conditions $[10,11]$.

Oil-containing is not the only problem of drilling waste contamination. Another issue is a big amount of salts, which are components of drilling fluid. Such salts as chlorides, sulfates, hydrocarbonates, sodium, and chlorine ions are the most dangerous for plants. These salts destroy cell membranes, reduce enzyme activity, and change protein metabolism [12].

A range of studies suggests nodule bacteria introduction (strains 423b, 282, etc.) into salt-contaminated soils to raise the amount of essential nutrients. Yellow melilot and blue alfalfa are used for phyto-amelioration $[13,14]$. These studies confirm the efficiency of nodule bacteria application which provides a stable growth of green basis without additional fertilizers.

\section{Materials and methods}

The system analysis methods were used in the theoretical research, the ecosystem approach being the methodological basis of the study. Laboratory studies were conducted according to the requirements of the regulatory documents. Conventional techniques, instruments, devices, and PC software were used for observation and recording. The experimental data were treated by methods of mathematical statistics.

The subject matter of the study is the drilling sludge of the Nivagal'skoe oil field in KMAO (cluster №924).

The scope of the study is the reclamation process considering the physical and chemical properties of the drilling sludge.

Drilling sludge is a dark grey hydrophobic oily substance that has a dense loamy texture and oil odor. Drilling sludge samples of the Nivagal'skoe oil field exploited by the Lukoil Company were taken for chemical analysis. X-ray fluorescence analysis was used to identify the elemental composition of samples. The results obtained are shown in Table 1.

Table 1. The results of XRF analysis of drilling sludge.

\begin{tabular}{lccc} 
& & $12.11 .20192: 24: 53$ PM \\
& & Calclated by UniQuant & Thermo Fisher Scientific \\
& & & $2.21: 28$ PM \\
\hline ARL OPT-2148 RH 50kV LiF200 LnSb AX06 & & Measured on & Helium \\
Method & X_UQ_He & X-ray Path: &
\end{tabular}




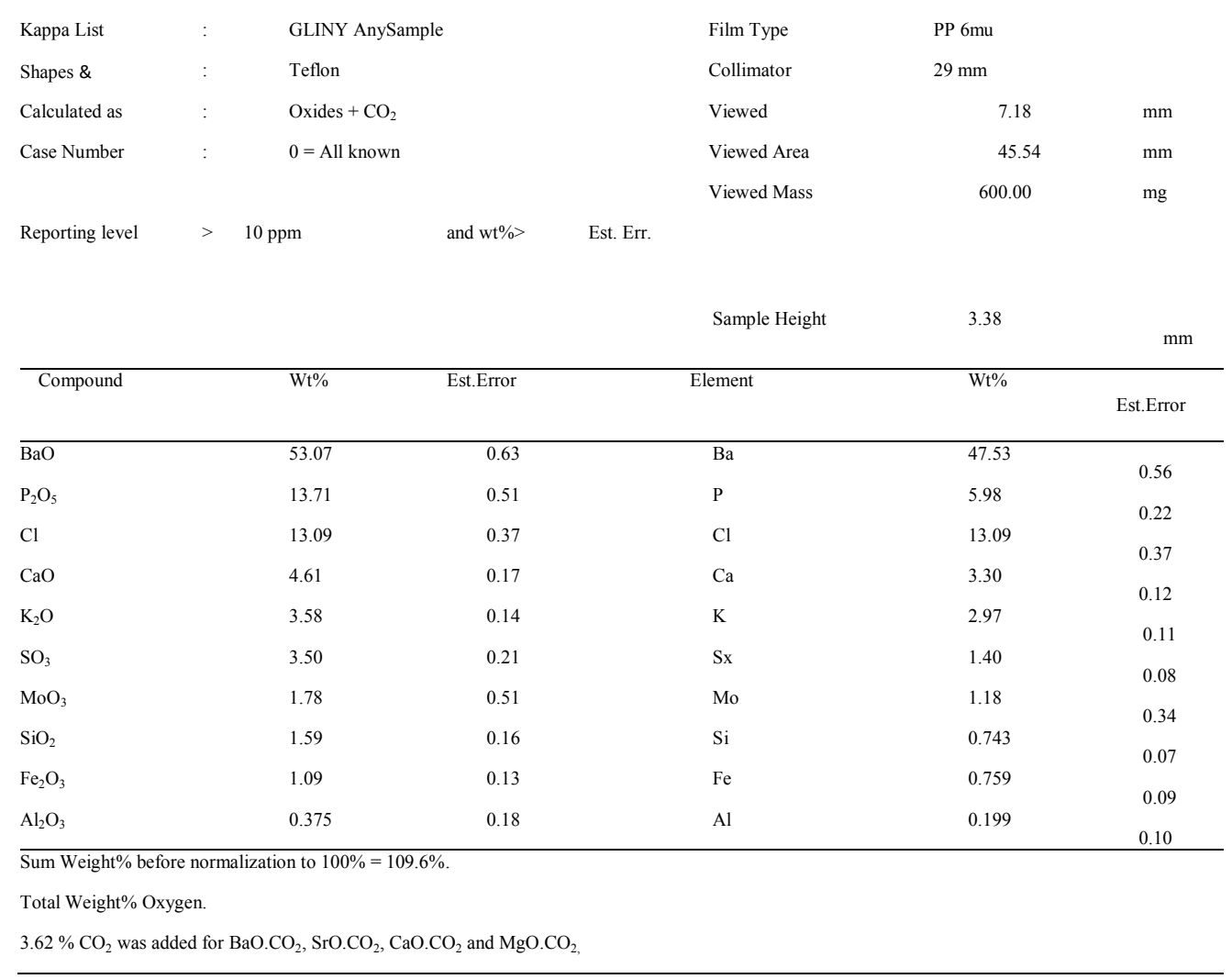

Chemical composition of the studying sample consists of following elements (in descending): barium $(\mathrm{Ba})-47.53 \%$, chlorine $(\mathrm{Cl})-13.09 \%$, phosphorus $(\mathrm{P})-5.98 \%$, potassium $(\mathrm{K})-2.97 \%$, sulfur $(\mathrm{S})-1.40 \%$, molybdenum $(\mathrm{Mo})-1.18 \%$, ferrum $(\mathrm{Fe})-$ $0.759 \%$, silicon $(\mathrm{Si})-0.743 \%$, aluminium $(\mathrm{Al})-0.199 \%$ [16]. Interreactions of chemical elements lead to the formation of complex salts which results in drilling waste salinity. According to chemical data, 8 types of salinization at different concentrations were chosen for experimental studies (Table 2).

Nodule bacteria living only on leguminous crop roots, clover, and lupine were chosen for the experiment. Following strains of nodule bacteria were used: 340b, 348a, 1260 for clover, and 367a, 363a, 375a for lupine.

Table 2. Salinization types and concentrations

\begin{tabular}{ccc}
\hline № & Salinization type & Concentrations \\
\hline 1 & $\mathrm{MgSO}_{4}$ & $0.3 \%, 0.8 \%, 1 \%, 2 \%$ \\
2 & $\mathrm{Na}_{2} \mathrm{SO}$ & $0.3 \%, 0.8 \%, 1 \%, 2 \%$ \\
3 & $\mathrm{NaCl}$ & $0.3 \%, 0.8 \%, 1 \%, 2 \%$ \\
4 & $\mathrm{NaHCO}_{3}$ & $0.1 \%, 0.5 \%, 0.8 \%, 1 \%$ \\
5 & $\mathrm{Na}_{2} \mathrm{CO}_{3}$ & $0.1 \%, 0.5 \%, 0.8 \%, 1 \%$ \\
6 & Sulphate-soda $\left(\mathrm{NaHCO}_{3}: \mathrm{NaCl}_{2}: \mathrm{Na}_{2} \mathrm{SO}_{4}(15: 1: 7)\right)$ & $<0.1 \%, 0.2 \%, 0.4 \%$ \\
7 & Sulphate-chloride $\left(\mathrm{NaHCO}_{3}: \mathrm{NaCl}: \mathrm{Na}_{2} \mathrm{SO}_{4}(1: 2.5: 2.3)\right)$ & $0.4 \%, 0.8 \%, 1.4 \%$ \\
8 & Gypsum $\left(\mathrm{Ca}\left(\mathrm{HCO}_{3}\right)_{2}: \mathrm{CaSO}_{4}: \mathrm{MgSO}_{4}: \mathrm{Na}_{2} \mathrm{SO}_{4}: \mathrm{NaCl}\right)$ & $0.15 \%, 0.3 \%, 0.6 \%, 3 \%$ \\
\hline
\end{tabular}

In order to fulfill the requirements of GOST standards, bean agar was put in a Petri dish firstly, after which chosen salts were added and nodule bacteria were introduced. Colonies 
recording was made on the 30th day. Bacteria amount per one $\mathrm{cm}^{2}$ was estimated and multiplied by the dish area. The experiment was carried out with triple repeatability. Recorded data on the amount of colony-forming units were put in a table.

\section{Results}

As a result of the experiment, the best survival rates for each strain of nodule bacteria at different concentrations were obtained. The survival rates of bacteria originated from clover and lupine were charted. The most typical survival charts are presented below.

1. Clover:

a. Strain 1360 has shown the best survival in sulphate-chloride salinization (Fig. 3 ) except for $0.4 \%$ concentration.

\section{Sulfate-chloride salinization}
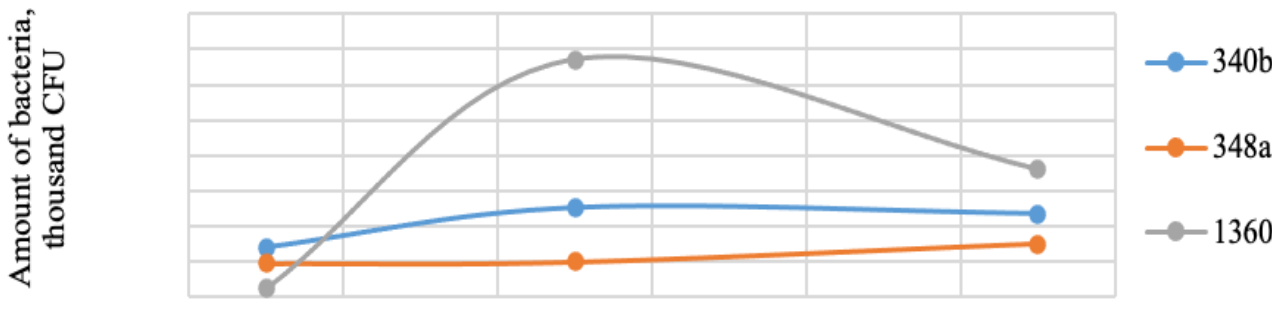

$\rightarrow-348 \mathrm{a}$

\section{Salt concentraion, \%}

Fig. 3. Survival chart for clover samples bacteria in sulphate-chloride salinization.

b. Strain 348a has shown the best survival in $\mathrm{MgSO}_{4}$ salinization (Fig. 4) regardless of salt concentration.

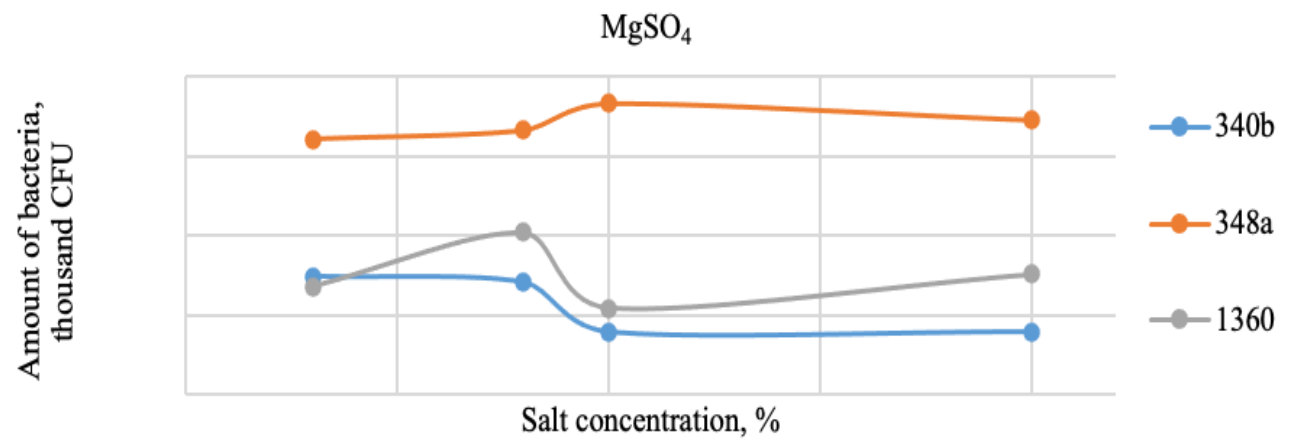

Fig. 4. Survival chart for clover samples bacteria in $\mathrm{MgSO}_{4}$ salinization.

c. The strains which have shown the best survival in $\mathrm{Na}_{2} \mathrm{CO}_{3}$ salinization differ depending on salt concentration (Fig. 5). 


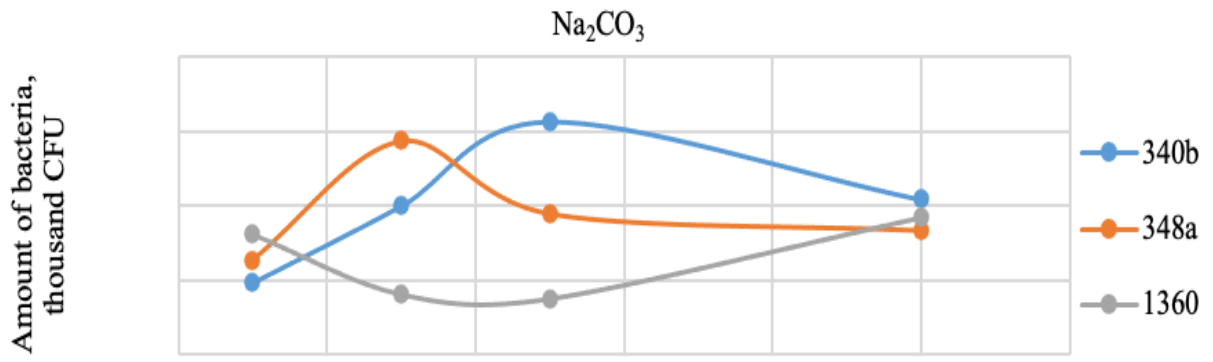

Salts concentration, \%

Fig. 5. Survival chart for clover samples bacteria in $\mathrm{Na}_{2} \mathrm{CO}_{3}$ salinization.

d. The best survival in gypsum salinization was shown for lower salt concentrations by $340 \mathrm{~b}$ and higher salt concentration by strain 1360 , but the increasing number of colonies with the growth of salts concentration was established for all the strains (Fig. $6)$.

\section{Gypsum salinization}
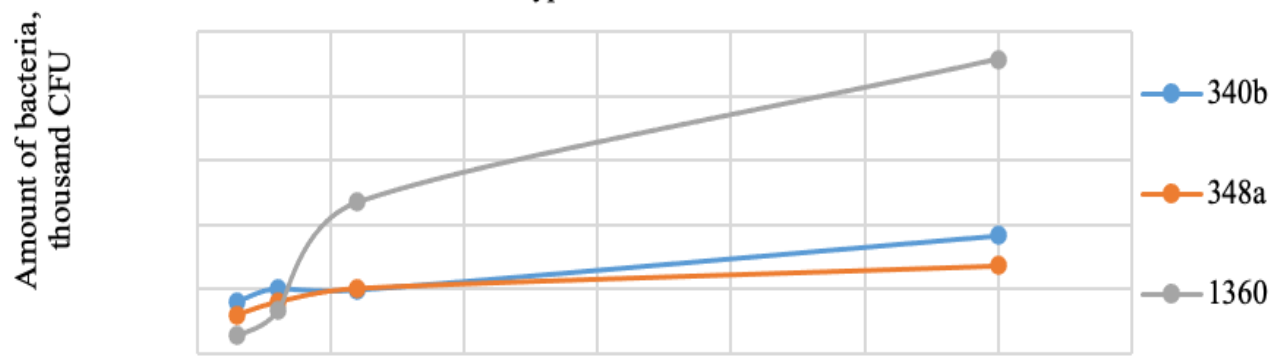

Salt concentration, $\%$

Fig. 6. Survival chart for clover samples bacteria in $\mathrm{Ca}\left(\mathrm{HCO}_{3}\right)_{2}: \mathrm{CaSO}_{4}: \mathrm{MgSO}_{4}: \mathrm{Na}_{2} \mathrm{SO}_{4}: \mathrm{NaCl}$ salinization.

2. Lupine:

a. Strain 367a has shown the best survival in $\mathrm{MgSO}_{4}$ salinization (Fig. 7) regard-less of the salt concentration.

$\mathrm{MgSO} 4$
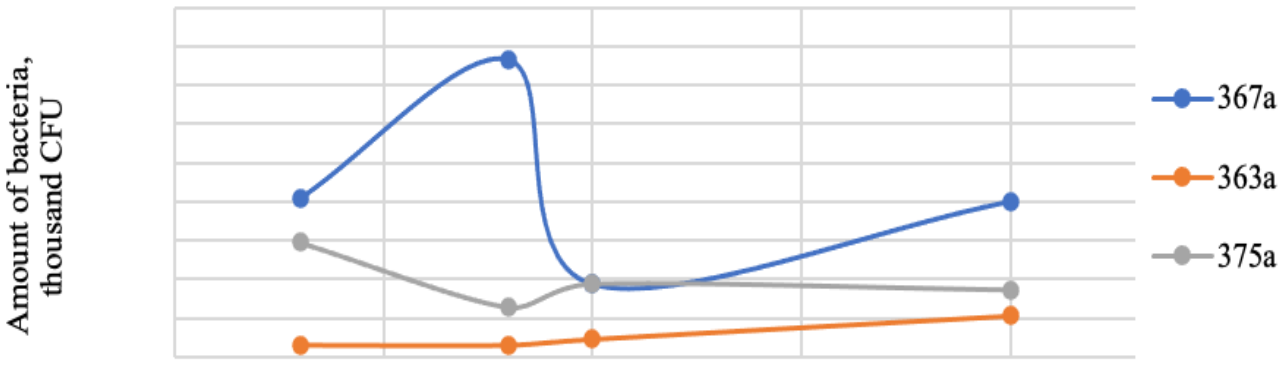

Salt concentration, $\%$

Fig. 7. Survival chart for lupine samples bacteria in $\mathrm{MgSO}_{4}$ salinization. 
b. The best survival in $\mathrm{Na}_{2} \mathrm{SO}_{4}$ salinization was shown for lower salt concentration by 363a and for higher salt concentration by strain 367a (Fig. 8).

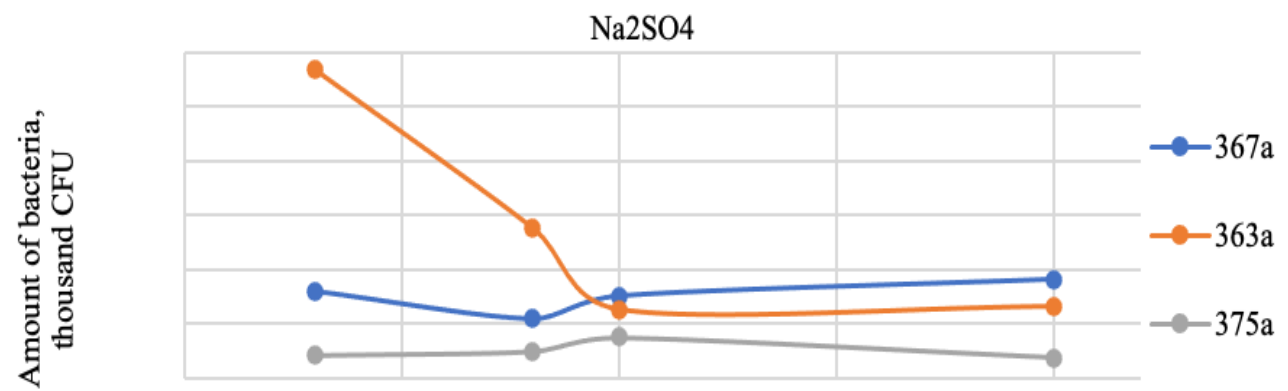

Salt concentration, \%

Fig. 8. Survival chart for lupine samples bacteria in $\mathrm{Na}_{2} \mathrm{SO}_{4}$ salinization.

c. Strain 363a has shown the best survival in sulphate-soda salinization (Fig. 9) regardless of salt concentration.

Sulphate-soda salinization
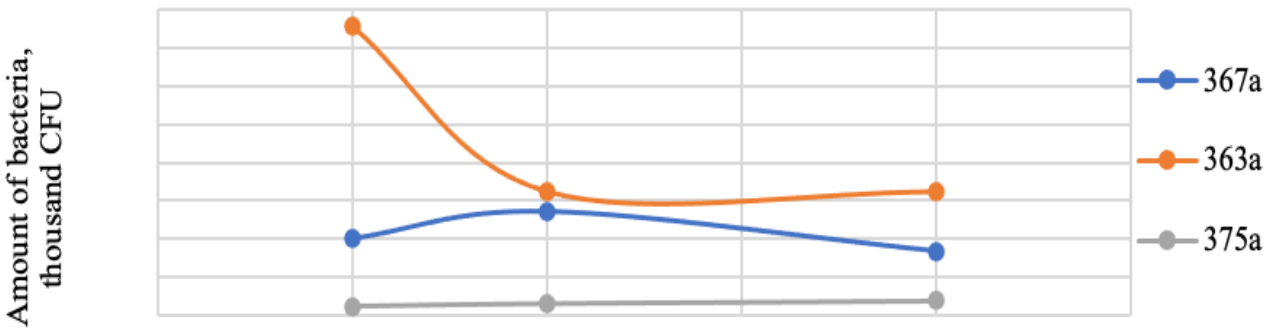

Salt concentration, \%

Fig. 9. Survival chart for lupine samples bacteria in $\mathrm{NaHCO}_{3}: \mathrm{NaCl}_{\mathrm{Na}} \mathrm{SO}_{4}(15: 1: 7)$ salinization.

d. Strain 367a has shown the best survival in $\mathrm{NaHCO}_{3}: \mathrm{NaCl}_{2} \mathrm{Na}_{2} \mathrm{SO}_{4} \quad(1: 2.5: 2.3)$ salinization (Fig. 10) in all salt concentrations.

\section{Sulphate-chloride salinization}
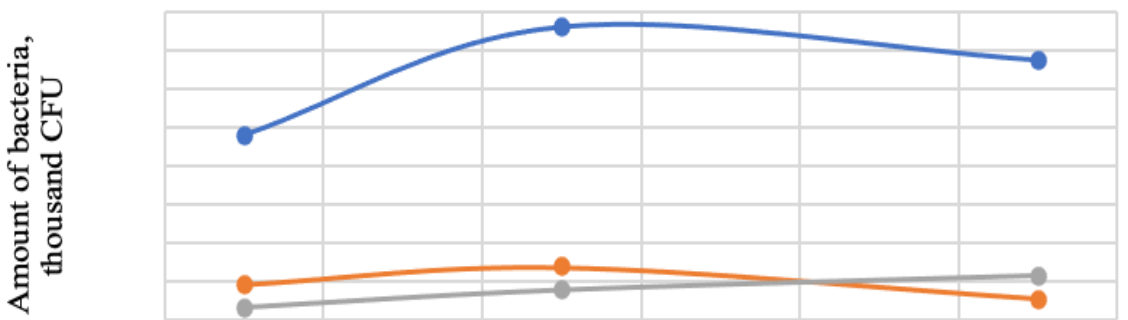

Salt concentration, $\%$

Fig. 10. Survival chart for lupine samples bacteria in chloride-soda salinization. 
The survival rates of control samples were also charted (Fig. 11). It has been shown that clover sample bacteria survival is generally higher than the survival of lupine sample bacteria. This result was found for all types of salinization.

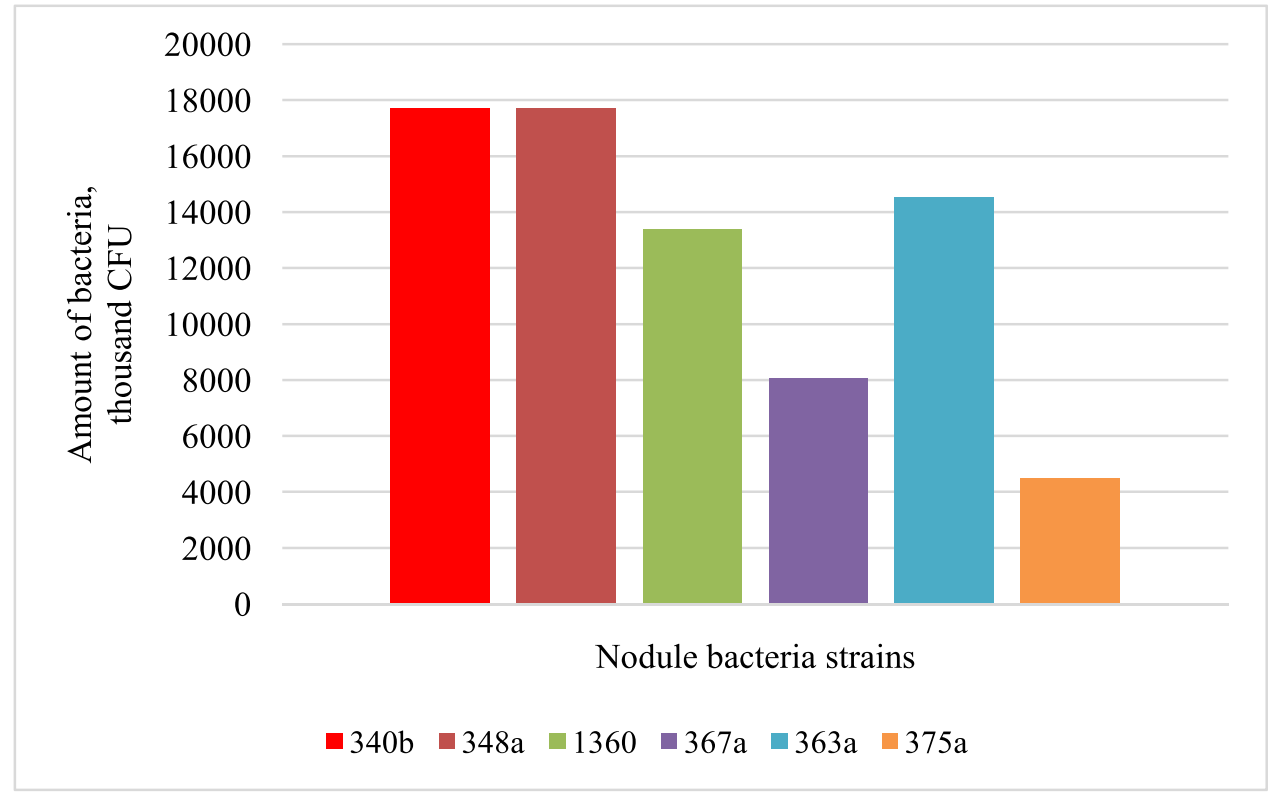

Fig. 11. Survival chart for control samples bacteria.

The results of colony-forming unit estimation have been put in Table 3 .

Table 3. The estimation of CFU of salt-tolerant strains of nodule bacteria.

\begin{tabular}{cccccc}
\hline $\begin{array}{c}\text { Salinization } \\
\text { type }\end{array}$ & Strain & \multicolumn{4}{c}{ Salts concentration, \% } \\
\hline $\mathrm{MgSO}_{4}$ & $340 \mathrm{~b}$ & 7412.1 & 0.8 & 1 & 2 \\
& $348 \mathrm{a}$ & 16034.3 & 16597.1 & 18303.3 & 17244.4 \\
& 1360 & 6807.0 & 10210.5 & 5445.6 & 7563.3 \\
& $367 \mathrm{a}$ & 4084.2 & 7639.0 & 1890.8 & 4008.6 \\
& $363 \mathrm{a}$ & 302.5 & 302.5 & 453.8 & 1058.9 \\
& $375 \mathrm{a}$ & 2949.7 & 1285.8 & 1890.8 & 1739.6 \\
\hline $\mathrm{Na}_{2} \mathrm{SO}_{4}$ & $367 \mathrm{a}$ & 3186.7 & 2193.4 & 3025.3 & 3630.4 \\
& $363 \mathrm{a}$ & 11345.0 & 5521.2 & 2526.5 & 2647.2 \\
& $375 \mathrm{a}$ & 832.0 & 983.2 & 1512.7 & 756.3 \\
\hline & & 0.1 & 0.3 & 0.5 & 1.0 \\
\hline $\mathrm{Na}_{2} \mathrm{CO}_{3}$ & $340 \mathrm{~b}$ & 4840.5 & 9983.6 & 15656.1 & 10428.4 \\
& $348 \mathrm{a}$ & 6353.2 & 14370.3 & 9454.2 & 8319.7 \\
& 1360 & 8092.8 & 4008.6 & 3706.0 & 9227.3 \\
\hline $\mathrm{Gypsum}$ & $340 \mathrm{~b}$ & 8092.8 & 10059.2 & 9832.3 & 3.0 \\
\hline
\end{tabular}




\begin{tabular}{|c|c|c|c|c|c|}
\hline \multirow[t]{3}{*}{ salinization } & $348 \mathrm{a}$ & 5975.0 & 7941.5 & 10134.9 & 13692.8 \\
\hline & 1360 & 2798.4 & 6574.6 & 23542.0 & 45682.5 \\
\hline & & 0.4 & 0.8 & 1.4 & \\
\hline \multirow{7}{*}{$\begin{array}{l}\text { Sulphate- } \\
\text { chloride } \\
\text { salinization }\end{array}$} & $340 \mathrm{~b}$ & 7033.9 & 12630.8 & 11798.8 & \\
\hline & $348 \mathrm{a}$ & 4764.9 & 4991.8 & 7545.2 & \\
\hline & 1360 & 1285.8 & 33505.6 & 18076.4 & \\
\hline & $367 a$ & 4771.6 & 7601.2 & 6731.4 & \\
\hline & $363 a$ & 907.6 & 1361.4 & 529.4 & \\
\hline & $375 a$ & 302.5 & 756.3 & 1134.5 & \\
\hline & & $<0.1$ & 0.2 & 0.4 & \\
\hline \multirow{3}{*}{$\begin{array}{l}\text { Sulphate- } \\
\text { soda } \\
\text { salinization }\end{array}$} & $367 a$ & 2004.4 & 2722.8 & 1663.9 & \\
\hline & $363 a$ & 7563.3 & 3252.2 & 3252.2 & \\
\hline & $375 a$ & 226.9 & 302.5 & 378.2 & \\
\hline \multirow[t]{6}{*}{ Control } & $340 \mathrm{~b}$ & 17698.2 & & & \\
\hline & $348 \mathrm{a}$ & 17698.3 & & & \\
\hline & 1360 & 13387.1 & & & \\
\hline & $367 a$ & 8055.0 & & & \\
\hline & $363 a$ & 14521.6 & & & \\
\hline & $375 a$ & 4462.4 & & & \\
\hline
\end{tabular}

\section{Discussion}

Analysis of the results indicates that the CFU amount for lupine samples bacteria in all types of salinization is lower than the CFU amount in control samples except for strain $375 \mathrm{a}$ in gypsum salinization at a concentration of $0.2 \%$. Therefore, all types of salinization have a suppression impact on strains 367a, 363a, 375a.

CFU amount for clover sample bacteria is also higher for control samples. The exceptions are:

1. Strain 348a in $\mathrm{MgSO}_{4}$ salinization at a concentration of $1 \%$;

2. Strain 1360 in $\mathrm{NaCl}$ salinization at a concentration of $0.3 \%$, in gypsum salinization at concentrations of $0.6 \%$ and $3 \%$, in sulphate-chloride salinization at concentrations of $0.8 \%$ and $1.4 \%$;

3. Strain $340 \mathrm{~b}$ in gypsum salinization at a concentration of $3 \%$.

However, all the samples have shown a positive survival regardless of the suppression influence of most salinization types on nodule bacteria strains. Therefore, the application of given strains for bioremediation is possible.

The solution to ecological and environmental problems requires an integrated approach. It is necessary to combine different waste treatment approaches and introduce new technologies for further use of decontaminated soils and the production of new building materials from drilling waste.

It is to be noted that the natural capacity of some contaminated lands can be restored only partially, therefore it is important to clearly understand the land purpose and use the best available technology to reduce the risk. 


\section{Conclusion}

Thus following tasks were fulfilled in the present study:

1. The chemical composition of the drilling sludge of the Navagal'skoe oil field was determined using XRF analysis.

2. The drilling sludge salts with the most adverse impact on living organisms were found.

3. Perspective salt-tolerant strains of nodule bacteria providing better atmospheric nitrogen fixation on the plants' roots, higher plants resistance at adverse conditions, suppressionof phytopathogenesis, and plant growth stimulation were identified as a result of the experiment.

4. The viability of nodule bacteria strains is confirmed which makes possible bioremediation of the soil contaminated by the drilling waste.

5. For the first time, the survival rates data for salt-tolerant strains of nodule bacteria 340b, 348a, 1360, 367a, 363a, 375a in 8 types of salinization at different concentrations were obtained.

It is also remarkable that the given method of bioremediation has resulted in a twofold increase of nitrogen amount in soil within one vegetation period to a concentration of $0.1 \%$ which is normal for clay and loam $(0.1 \%-0.15 \%)$. The increase of phosphates amounts in soil within one vegetation period to a level of $29-41 \mathrm{mg} / \mathrm{kg}$ has also been noted, while an average level for KMAO makes $38.8 \mathrm{mg} / \mathrm{kg}$ and MPC is equal to $200 \mathrm{mg} / \mathrm{kg}$ (Animal, forest and environment control service of Khanty-Mansi Autonomous Area 2020).

The tendency for an increase of essential nutrients amount is supposed to be stable, which will have a positive impact on plant growth.

Further research may focus on comparing different methods of decontamination and reclamation of contaminated soilpolluted with drilling sludge and their interaction with this method.

\section{References}

1. Gadzhiev, I. M. et al Technogenic landscapes ecology and reclamation. (Novosibirsk: Nauka. Siberian department, 1992).

2. PJSC Surgutneftegaz Technical documentation for new technology "Sludge pit construction, operation and soil remediation for Russian forestlands in West Siberia" (2019).

3. E.A. Pichugin The estimation of drilling sludge impact on the environment, Young Scientist 9, 122-123 (2013).

4. V.V. Velkov Bioremediation: principles, problems, approaches, Biotechnology, 3-4, 20 27 (1995).

5. O. Sh. Beliavskaia, et al Disposal of chlorine ion in drilling sludge water extract in the north of Tyumen region, 10th intern. scientific and technical conference; Proc. Intern. Conf., Omsk, (2020).

6. M.S. Gilyarov Biology. Encyclopedical dictionary. (Moscow 1999).

7. D.G. Zvygintsev The methods of soil microbiology and biochemistry. (Moscow: Moscow State University Publishing 1991).

8. D.S. Orlov Soil chemistry. (Moscow: Higher School, 1978).

9. A.N. Loginov, et al Biotechnological methods of environment cleansing from technogenic contamination. (Ufa: Reaktiv, 2000). 
10. N.I. Ismailov, et al The current state of oil contaminated soils reclamation, Restoration of oil contaminated soil ecosystems, 222-236 (1988).

11. A.V. Nazarov, The impact of oil soil contamination on plants, Bulletin of Perm State University 5(10), 134-141 (2007).

12. G.G. Yagafarova, et al The disposal of environmentally hazardous waste, Oil and Gas Business, 2, 530-551.

13. V.S. Petukhova, et al Comparative evaluation of methods of drilling sludge biological reclamation, Ural Agrarian Bulletin 1(155), 35-39 (2017).

14. L.N. Skipin, et al The parameters of nodule bacteria vital activity in conditions of edaphic factors, The Bulletin of KrasnoyarskState Architecture and Engineering University 6, 103-108 (2014).

15. O.Sh. Beliavskaia, et al The particular features of bioremediation of hydrocarbons exploration waste in the circumpolar region, Ecological safety and sustainable development of urban lands; Proc. Scientific conf., Nizhny Novgorod, (2019). 